Modi f i cat i on of ther nosensitivity and chemosensi ti vi ty i nduced by conbi ned treat ment $s$ wi th hyperther ma and adri amyci $n$

\begin{tabular}{|l|l|}
\hline 著者 & $\begin{array}{l}\text { Hayashi Sachi ko, Kano Ei i chi, Tsuj i Koh, } \\
\text { Fur ukawa- Fur uya Nasayo, Yoshi kawa Shi nj i, } \\
\text { Hat ashi ta Nasanori, Nat sumøt o Hi deki, Ji n } \\
\text { Zhao- Hui, Oht subo Toshi o, K t ai Ryuhei }\end{array}$ \\
\hline $\begin{array}{l}\text { j our nal or } \\
\text { publ i cat i on ti tl e }\end{array}$ & I nt er nat i onal Jour nal of Mol ecul ar Medi ci ne \\
\hline vol une & 8 \\
\hline page range & $417-422$ \\
\hline year & $2001-08$ \\
\hline URL & ht t p: //hdl . handl e. net /10098/1069 \\
\hline
\end{tabular}




\title{
Modification of thermosensitivity and chemosensitivity induced by combined treatments with hyperthermia and adriamycin
}

\author{
SACHIKO HAYASHI ${ }^{1}$, EIICHI KANO', KOH TSUJI ${ }^{4}$, MASAYO FURUKAWA-FURUYA $^{1}$, SHINJI YOSHIKAWA ${ }^{5}$,

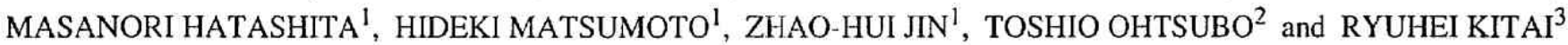 \\ Departments of ${ }^{1}$ Experimental Radiology, ${ }^{2}$ Otorhinolaryngology and ${ }^{3}$ Neurosurgery, Fukui Medical University, Matsuoka, \\ Fukui 910-1 193; ${ }^{4}$ Department of Radiology, National South Wakayama Hospital, Tanabe, Wakayama 646-0011; \\ ${ }^{5}$ Department of Bacteriology, Nara Medical University, Kashihara, Nara 634-8521, Japan
}

Received June 18, 2001; Accepted July 27, 2001

\begin{abstract}
Both adriamycin (ADM) and hyperthermia show thermal chemo-enhancement. Tolerance induction against ADM in heated cells has been reported resulting in clinical difficulty of cancer therapy. We investigated thermoenhancement induced with $\operatorname{ADM}(0.2 \mu \mathrm{g} / \mathrm{ml})$ treatment alone or combined with $\mathrm{ADM}$ and $42^{\circ} \mathrm{C}$ hyperthermia in Chinese hamster V79 cells in vitro. Intracellular accumulation of hsc70 and hsp72 proteins after hyperthermia or ADM was observed to examine the possible relationship between cell killing effect and their accumulations. Thermosensitivity of V79 cells at $42^{\circ} \mathrm{C}$ after the simultaneous treatments with ADM showed marked thermo-enhancement within the short-term treatments for less than $1 \mathrm{~h}$, while the combined treatments for longer than $1 \mathrm{~h}$, the cells showed reduced thermosensitivity. Survival from the simultaneous treatments for less than $1 \mathrm{~h}$ was reduced markedly less than the single treatment both with ADM or $42^{\circ} \mathrm{C}$ hyperthermia alone. Thermotolerance was markedly induced in a step-up hyperthermia $\left(42^{\circ} \mathrm{C} 2 \mathrm{~h}-44^{\circ} \mathrm{C}\right)$. The combined treatments with $\mathrm{ADM}$ and $44^{\circ} \mathrm{C}$ hyperthermia following the $42^{\circ} \mathrm{C}$ preheating alone does not inhibit thermotolerance development. The combined treatments with ADM and $42^{\circ} \mathrm{C}$ preheating showed markedly interactive cell killing, but no thermo-enhancement to the following $44^{\circ} \mathrm{C}$ hyperthermia was shown. The leveling slope of the $44^{\circ} \mathrm{C}$ heating period - survival curve was drawn. In the Western blot analyses, hsc70 existed constitutively in the V79 cells. Following the 42 or $44^{\circ} \mathrm{C}$ hyperthermia alone, intracellular accumulation of hsp 72 was determined. $\mathrm{ADM}$ treatment alone
\end{abstract}

Correspondence to: Professor Eiichi Kano, Department of Experimental Radiology, Fukui Medical University, Matsuoka, Fukui 910-1193, Japan

E-mail: hokikano@fmsrsa.fukui-med.ac.jp

Key words: hyperthermia, adriamycin, combined treatments, modified thermosensitivity, modified chemosensitivity, Hsc70, Hsp72, Chinese hamster V79 cells did not induce any accumulation of hsp 72. In the simultaneous treatments with ADM and hyperthermia, the accumulation of hsp72 was markedly reduced. The accumulation of hsp72 after the combined treatment with ADM and hyperthermia was not observed as markedly as that after hyperthermia alone.

\section{Introduction}

Adriamycin (14-hydroxydaunorubicin, doxorubicin, NSC123127 or adriblastin) was adopted for cancer therapy in 1969 (1). This chemical substance, one of the anthracyclines, was isolated from cultured Streptomyces peucetius var. caesius by Arcamone et al, and showed anti-tumor effect (1). ADM has been adopted for human cancer therapy and treated alone or in the interdisciplinary therapy combined with radiation, hyperthermia and/or a variety of the other anticancer drugs (2). Mechanism of action of ADM has been widely investigated. It was reported that DNA treated with low concentration of ADM resulted in the single strand breaks among a variety of cell lines (3), and that double strand breaks increased in accordance with increase in ADM concentration. It was first considered that ADM intercalates to the adjacent base pairs of the double stranded DNA and results in inhibition of enzymes concerning DNA replication and transcription $(4,5)$. However, it was suggested that another target existed on nucleic membrane that altered the structure function of the membrane (6). Hyperthermia has been shown interactive effect in combined treatments with a variety of anticancer drugs, in which interactive effect of combined treatment with ADM and hyperthermia is reported (7). It was first reported that cells exposed to step-up heating (i.g. 42 $\left.44^{\circ} \mathrm{C}\right)$ tolerated the determining heating $\left(44^{\circ} \mathrm{C}\right)(8,9)$. Hsp70 family, including hsc70 (10) and hsp72 (11) proteins, is transcriptionally induced as stress protein due to transitional or sublethal damage such as hyperthermia $(11,12)$, inhibition of metabolism, heavy metals, virus infection, UV (13) or ionizing radiation (14) and DNA damaging agents (15). Stress protein synthesis is regulated by stress-specific transcription factors, molecular chaperons, that protect cells f. om stress, taking an important role to maintain homeostasis (16). Since interactive effect of ADM and hyperthermia is 
not observed clearly in in vivo experiments or clinical results, mechanism of the interaction has been investigated in quantitative colony formation by surviving cells in vitro and Western blot analyses of hsp70 family in the present study.

\section{Materials and methods}

Cells and culture medium. Chinese hamster V79 cells (17) were colonially cloned and used for all the present experiments, and cultured in the medium MLN-15, 11 of which contained $730 \mathrm{ml}$ of Eagle's MEM solution (Nissui Pharmaceutical Co., Tokyo, Japan), $20 \mathrm{ml}$ of $2.5 \% \mathrm{w} / \mathrm{v}$ autoclaved lactalbumin hydrolysate solution (Difco Laboratories, Detroit, MI, USA), $100 \mathrm{ml}$ of NCTC-135 solution (Gibco Laboratories, Grand Island. NY, USA) and $150 \mathrm{ml}$ of inactivated new born calf serum (Gibco).

Hyperthermia and the surviving cell colony formation. Hyperthermia was carried out by immersion of culture flasks of the tightened screw tops in a temperature-regulated water bath (Model EPS-47, Toyo Seisakusho Co., Tokyo, Japan) pre-set at 42 or $44^{\circ} \mathrm{C}$. The temperature was maintained within the error of $\pm 0.05^{\circ} \mathrm{C}$ of the pre-set temperatures as measured by a thermistor (Model D116-125I, TaKaRa Thermistor Instruments Co., Yokohama, Japan). Each flask was exposed to hyperthermia or ADM treatment for graded periods (18). The cells were finally cultured in a $\mathrm{CO}_{2}$ incubator (Tabai-Espec LNA-3 DH, Osaka, Japan) in the flasks for 5-10 days to allow growth for visible colony formation of the surviving cells from the treatment of hyperthermia or ADM. The surviving cell fractions were determined using a colony forming assay (18).

Treatment with ADM. ADM (Kyowa Hakko Co., Tokyo, Japan) was dissolved in the culture medium at the final concentration of $0.2 \mu \mathrm{g} / \mathrm{ml}$ for all the present treatment, that was about a half of the standard clinical dose range (drug weight/human body weight). The adhered cells on the inner face in the bottom of the flasks were exposed with ADM by replacement with $6 \mathrm{ml}$ of the ADM solution in MLN-15 for graded periods, the ADM solution was chased, the adhered cells were rinsed twice and refed with $6 \mathrm{ml}$ of the $37^{\circ} \mathrm{C}$ culture medium, MLN-15. Thus treated flasks were incubated stationarily for visible colony formation.

Hsc70 and hsp72 assays. After the variety of those isotoxic treatments, the cells were incubated at $37^{\circ} \mathrm{C}$ for graded interval periods less than $24 \mathrm{~h}$, and the accumulated amounts of hsc70 and hsp72 in the cells were examined by Western blot analysis (19). The adopted monoclonal antibody against hsp72 was C92F3A-5 (StressGen Biotechnologies Corp., Victoria, BC, Canada) while that against hsc70 was BB70 (StressGen Biotechnologies Corp.).

\section{Results}

$42^{\circ} \mathrm{C}$ alone, $A D M$ alone or the simultaneously combined treatments. In heating period - survival relation ship of V79 cells at $42^{\circ} \mathrm{C}$, the thermosensitivity was moderate. In the initial part of the survival curve, sublethal thermal damage repair

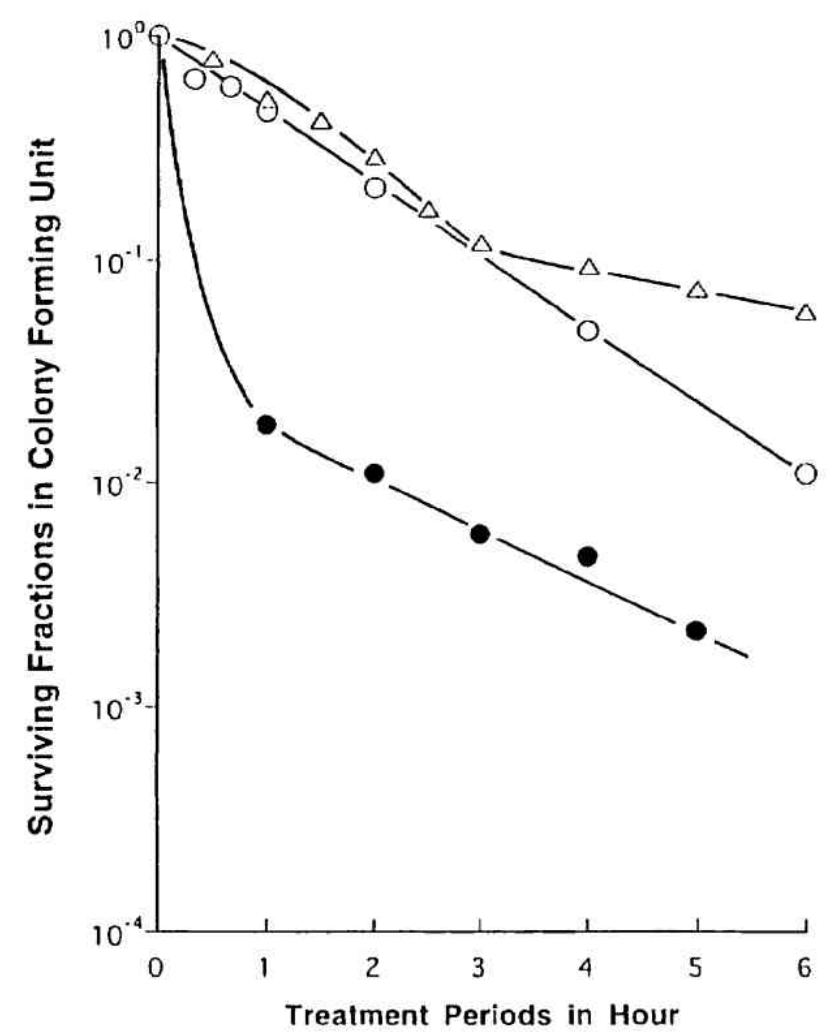

Figure 1. Effect of simultaneous treatment with ADM $0.2 \mu \mathrm{g} / \mathrm{ml}$ on survival of V79 cells from $42^{\circ} \mathrm{C}$ hyperthermia. Ordinate: log surviving fractions in colony forming unit. Abscissa: treatment periods of $\mathrm{ADM}, 42^{\circ} \mathrm{C}$ or $\mathrm{ADM}$ at $42^{\circ} \mathrm{C}$ in hour. Open circles represent surviving fractions from ADM alone. Open circles show exponential regression to the graded treatment periods with ADM but no apparent repair from sublethal chemical damage appeared. Open triangles represent surviving fractions from $42^{\circ} \mathrm{C}$ hyperthermia alone. The survival curve represents repair from sublethal thermal damage (SLTDR) in shoulder profile followed by gentler slope in exponential regression indicating induction of thermotolerance after $3 \mathrm{~h}$ hyperthermia at $42^{\circ} \mathrm{C}$. Closed circles represent surviving fractions from simultaneously combined treatments with $\mathrm{ADM}$ and $42^{\circ} \mathrm{C}$ hyperthermia resulting in markedly steeper regression of the surviving fraction for the initial $1 \mathrm{~h}$ of the treatment followed by the another exponential regression with reduced lethal sensitivity in the markedly gentler slope for $5 \mathrm{~h}$. The error bars on the symbols represent standard errors of three replicate flasks. Symbols without error bar represent that those bars are within the symbols.

(SLTDR) was shown in the profile of 'shoulder' followed by exponential regression appearing within the $42^{\circ} \mathrm{C}$ heating period for $1.5-3 \mathrm{~h}$ in the survival curve. In the heating period for more than $3 \mathrm{~h}$, surviving fractions further regressed exponentially in markedly gentler slope of the survival curve as thermotolerance developed as shown with open triangles in Fig. 1. The ADM $(0.2 \mu \mathrm{g} / \mathrm{ml})$ treatment period - survival curve at $37^{\circ} \mathrm{C}$ showed a simple exponential regression as shown with open circles in Fig. 1. Simultaneous treatments with the $42^{\circ} \mathrm{C}$ hyper-thermia and the ADM resulted in the regression curve of the surviving fraction with markedly steeper slope for the initial $\mathrm{l} \mathrm{h}$ of the treatment, followed by the gentler exponential regression for further $4 \mathrm{~h}$ so far as assayed as shown with closed circles in Fig. 1. $T_{0}$ values, treatment period required to reduce survivals by $1 / \mathrm{e}$ in the compartment of exponential regression, are shown in Table I. In the combined treatment with $42^{\circ} \mathrm{C}$ hyperthermia and ADM, the lethal sensitivity for the initial $1 \mathrm{~h}$ was markedly 
Table I. $\mathrm{T}_{0}$ values of V79 cells in survivals from treatment with $42^{\circ} \mathrm{C}, \mathrm{ADM}$ or $42^{\circ} \mathrm{C}$ and $\mathrm{ADM}$.

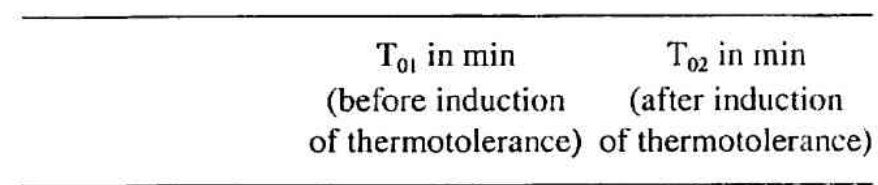

$42^{\circ} \mathrm{C}$ hyperthermia

111

183

ADM in $0.2 \mu \mathrm{g} / \mathrm{ml}$ 78

$42^{\circ} \mathrm{C}$ and $\mathrm{ADM}$

12

118

$\mathrm{T}_{0}$ value, incubation period required to reduce surviving fraction by $1 / \mathrm{e}$ in the exponentially regressing compartment of treatment period - survival curve in colony forming unit.

higher but followed by an exponential regression for the reduced lethal sensitivity for more than $1 \mathrm{~h}$, while treatment with $\mathrm{ADM}$ alone showed a constant lethal sensitivity as shown in Fig. 1.

Enhancement effect of $42^{\circ} \mathrm{C}$ preheating on the lethal chemosensitivity of thermotolerant V79 cells to $A D M$, and effect of $A D M$ on survival reduction of step-up $\left(42-44^{\circ} \mathrm{C}\right)$ thermotolerant V79 cells. The thermotolerance of V79 cells was induced by $42^{\circ} \mathrm{C}$ preheating for $2 \mathrm{~h}$. Chemosensitivity of the thermotolerant V79 cells to ADM was enhanced rather than the chemosensitivity to ADM alone. However, lethal sensitivity of the thermotolerant V79 cells to simultaneous treatments together with $\mathrm{ADM}$ and $44^{\circ} \mathrm{C}$ hyperthermia $\left(42^{\circ} \mathrm{C}\right.$ for $2 \mathrm{~h}$ alone $-44^{\circ} \mathrm{C}$ for graded periods in min with $\mathrm{ADM}$ ) was markedly interactive in the combined treatment for less than the initial $10 \mathrm{~min}$ followed by markedly gentle lethal sensitivity, which was similar to those for $44^{\circ} \mathrm{C}$ lethal thermosensitivity of $42-44^{\circ} \mathrm{C}$ step-up thermotolerant cells as shown with open triangles in Fig. 2.

Interactive effect of simultaneous treatments together with $42^{\circ} \mathrm{C}$ and $A D M$ for $2 \mathrm{~h}$ on thermo-chemo-enhancement, and effect of $A D M$ on induction of the step-up thermotolerance during the $42^{\circ} \mathrm{C}$ preheating for $2 \mathrm{~h}$ as determined by the $44^{\circ} \mathrm{C}$ hyperthermia. Surviving fraction from $42^{\circ} \mathrm{C}$ preheating for $2 \mathrm{~h}$ alone in the $42-44^{\circ} \mathrm{C}$ step-up heating was about $40 \%$. Surviving fraction from $\mathrm{ADM}$ treatment alone at $37^{\circ} \mathrm{C}$ for $2 \mathrm{~h}$ was about $20 \%$. Therefore theoretical survival fraction from the combined treatments should be about $8 \%(0.4 \times 0.2)$ unless there was any interactive effect. However, the practical surviving fraction from the combined treatments together with $\mathrm{ADM}$ and $42^{\circ} \mathrm{C}$ hyperthermia both for $2 \mathrm{~h}$, was about $1 \%$, that was markedly lower than the theoretically estimated $8 \%$. The resulted surviving fraction was much less than the theoretically estimated as shown on the ordinate of Fig. 3 , suggesting the interactive effect between the treatments of $\mathrm{ADM}$ and $42^{\circ} \mathrm{C}$ hyperthermia. Surviving cells from the combined treatments with $\mathrm{ADM}$ and $42^{\circ} \mathrm{C}$ hyperthermia for $2 \mathrm{~h}$ were ultimately thermotolerant in their $44^{\circ} \mathrm{C}$ lethal thermosensitivity to the following $44^{\circ} \mathrm{C}$ hyperthermia

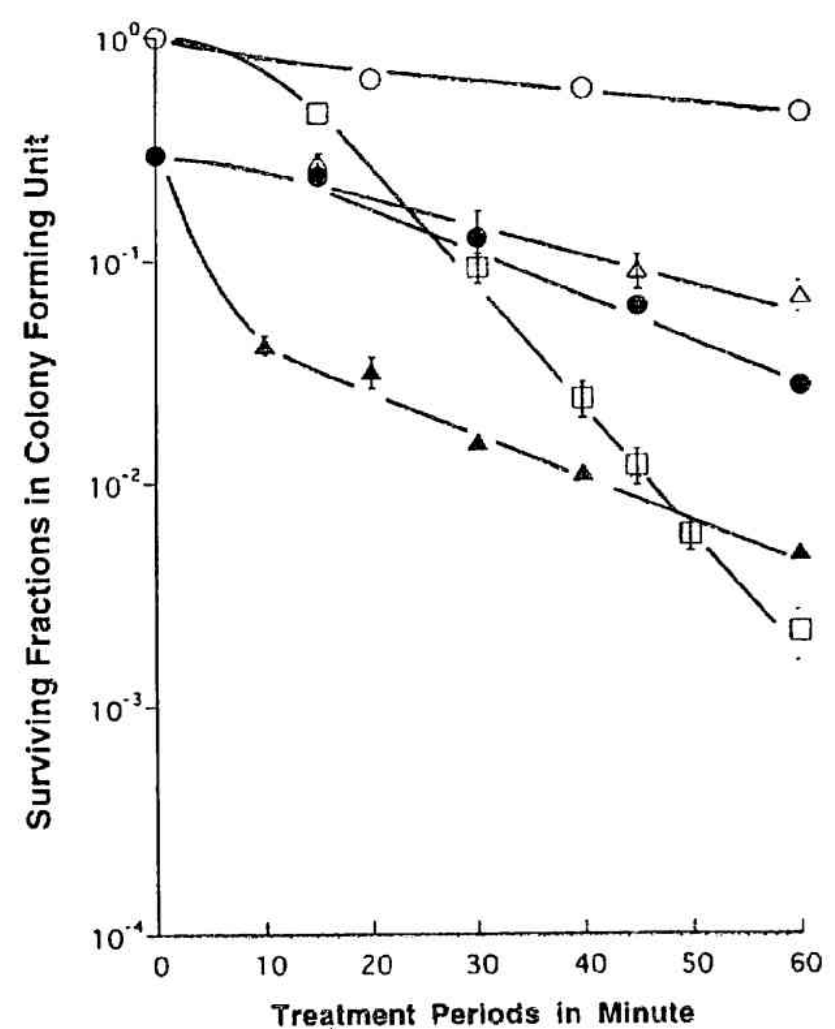

Figure 2. Effect of ADM on survival from $44^{\circ} \mathrm{C}$ hyperthermia in $42^{\circ} \mathrm{C}$ preheated thermotolerant V79 cells and effect of $42^{\circ} \mathrm{C}$ preheating on survival from ADM treatment at $37^{\circ} \mathrm{C}$. Ordinate: $\log$ surviving fractions in colony forming unit. Abscissa: treatment periods of $\mathrm{ADM}, 44^{\circ} \mathrm{C}$ hytperthermia alone or $\mathrm{ADM}$ at $44^{\circ} \mathrm{C}$ in min. Open circles and open squares represent surviving fractions from $A D M$ alone and $44^{\circ} \mathrm{C}$ hyperthermia alone, respectively. Open triangles represent surviving fractions of $42^{\circ} \mathrm{C}$ preheated thermotolerant $V 79$ cells, from $44^{\circ} \mathrm{C}$ hyperthermia for graded periods. Closed circles represent surviving fractions from $A D M$ treatment for graded periods at $37^{\circ} \mathrm{C}$ after $42^{\circ} \mathrm{C}$ preheating for $2 \mathrm{~h}$. A closed circle on the ordinate represents a survival from $42^{\circ} \mathrm{C}$ for $2 \mathrm{~h}$ alone. Closed triangles represent surviving fractions from ADM at $44^{\circ} \mathrm{C}$ for graded periods after $42^{\circ} \mathrm{C}$ preheating for $2 \mathrm{~h}$, which was interactive in the combined treatment for less than 10 min followed by an exponential regression in reduced lethal sensitivity, and which was similar to those for $44^{\circ} \mathrm{C}$ lethal thermosensitivity of step-up $\left(42-44^{\circ} \mathrm{C}\right)$ thermotolerant cells. The error bars on the symbols represent standard errors of three replicate flasks. Symbols without error bar represent that those bars are within the symbols.

regardless that the ADM was maintained through the $44^{\circ} \mathrm{C}$ hyperthermia. The marked interactive effect of the treatments together with $42^{\circ} \mathrm{C}$ hyperthermia and ADM was observed but the surviving cells from the combined simultaneous treatments (ADM and $42^{\circ} \mathrm{C}$ ) showed almost no apparent thermosensitivity to the following $44^{\circ} \mathrm{C}$ hyperthermia as shown in Fig. 3 .

We further investigated the time course of intra-cellular accumulation of hsc70 and hsp 72 proteins during the $37^{\circ} \mathrm{C}$ incubation interval between the treatment and Western blotting.

Western blot analyses after the variety of treatments with $A D M$, $42^{\circ} \mathrm{C}$ and $44^{\circ} \mathrm{C}$ hyperthermia. The $37^{\circ} \mathrm{C}$ interval periods after tine variety of the treatments and the Western blot ranged from 0 to $24 \mathrm{~h}$. Time course of the intracellular accumulation of hsc 70 or hsp 72 protein was qualitatively analyzed by 


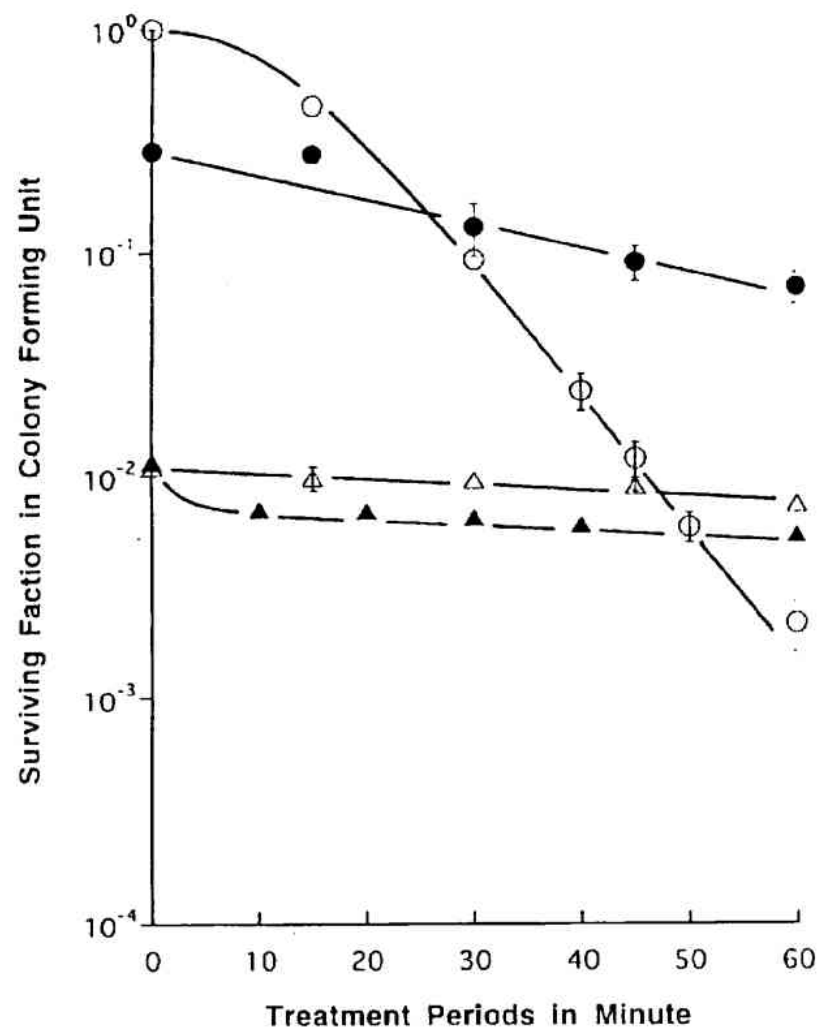

Figure 3. Effect of ADM on induction of thermotolerance or thermoenhancement during $42^{\circ} \mathrm{C}$ preheating for $2 \mathrm{~h}$ in V79 cells. Ordinate: $\log$ surviving fractions in colony forming unit. Abscissa: periods of $44^{\circ} \mathrm{C}$ hyperthermia in min. Open circles represent surviving fractions from $44^{\circ} \mathrm{C}$ hyperthermia alone. Closed circles represent surviving fractions, of $42^{\circ} \mathrm{C}$ preheated cells for $2 \mathrm{~h}$, from $44^{\circ} \mathrm{C}$ hyperthermia for graded periods. Open triangles represent surviving fractions, of pretreated cells together with $42^{\circ} \mathrm{C}$ and $\mathrm{ADM}$ for $2 \mathrm{~h}$, from $44^{\circ} \mathrm{C}$ hyperthermia for graded periods. Closed triangles represent surviving fractions, of cells pretreated together with $42^{\circ} \mathrm{C}$ and $\mathrm{ADM}$ for $2 \mathrm{~h}$, from the treatment together with $44^{\circ} \mathrm{C}$ hyperthermia and $\mathrm{ADM}$ for graded periods. Closed circle on the ordinate represents surviving fraction from $42^{\circ} \mathrm{C}$ alone for $2 \mathrm{~h}$. Semiclosed triangle on the ordinate represents surviving fraction from ADM treatment alone for $2 \mathrm{~h}$. Closed and open triangles on the ordinate represent surviving fractions from ADM and $42^{\circ} \mathrm{C}$ hyperthermia for $2 \mathrm{~h}$. Surviving fractions of cells pretreated together with $42^{\circ} \mathrm{C}$ and $\mathrm{ADM}$ was markedly decreased as shown by the open or closed triangle on the ordinate indicating the marked interactive cell killing, but the induced thermotolerance was markedly appeared by the further treatment with $44^{\circ} \mathrm{C}$ hyperthermia regardless of ADM treatment. The error bars on the symbols represent standard errors of three replicate flasks. Symbols without error bar represent that those bars are within the symbols.

Western blotting. The qualitative observations suggested as follow'; a) accumulation of hsc70 did not appreciably change by the ADM treatment during the $0-24 \mathrm{~h}$ interval incubation between ADM treatment and Western blot; b) accumulation of hsc70 increased by the $42^{\circ} \mathrm{C}$ hyperthermia alone but was not significantly different; c) increase in hsc70 accumulation after the combined treatments with $\mathrm{ADM}$ and $42^{\circ} \mathrm{C}$ hyperthermia was not observed significantly; d) hsc70 accumulation after the $44^{\circ} \mathrm{C}$ hyperthermia alone increased but was not significant; e) hsc70 accumulation after the combined treatment with $\mathrm{ADM}$ and $44^{\circ} \mathrm{C}$ hyperthermia was observed but not significant; f) the hsp72 after the ADM treatment at $37^{\circ} \mathrm{C}$ was not appreciably accumulated during the interval incubation periods for $0-24 \mathrm{~h} ; \mathrm{g})$ the hsp72 was

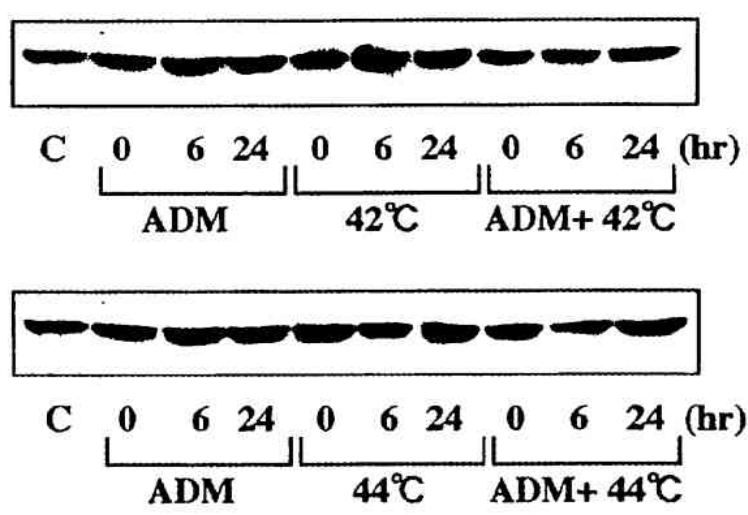

Figure 4. Hsc70 accumulation of $\mathrm{V} 79$ cells treated with $\mathrm{ADM}, 42^{\circ} \mathrm{C}$ (upper panel) or $44^{\circ} \mathrm{C}$ (lower panel) hyperthermia, or the combination with ADM and hyperthermia, after the graded periods of incubation intervals. Time course of intracellular accumulation of hsc70 in V79 cells after the treatments with ADM, hyperthermia or the combination were examined by Western blotting as shown. Numerals on horizontal line of the panels represent $37^{\circ} \mathrm{C}$ incubation intervals in hour between the treatments of ADM, hyperthermia or the combination and the blotting, respectively, and the ' $C$ ' on the left of the panels represent the lane for hsc70 of the non-treated control V79 cells. Each treatment period in the upper panel was designed for $3 \mathrm{~h}$ for $\mathrm{ADM}$ alone, $5 \mathrm{~h}$ for $42^{\circ} \mathrm{C}$ alone and $30 \mathrm{~min}$ for the combined treatments (surviving late in C.F.U. of $10 \%$, respectively), while in the lower panel $20 \mathrm{~min}$ for $44^{\circ} \mathrm{C}$ alone and $10 \mathrm{~min}$ for the combined treatments (surviving late in C.F.U. of $30 \%$, respectively). Treatment periods in the upper and lower pancls were designed to give isotoxic effect of the cell killing, respectively. The incubated cells were examined for hsc70 accumulation by Western blotting, and transferred on the Poly-Screen PVDF membrane 0-24 h after the incubation interval. Stained hsc70 electrophoretic bands were cut and picked up from the membrane and shown. Six and $24 \mathrm{~h}$ after the $42^{\circ} \mathrm{C}$ hyperthermia for $5 \mathrm{~h}$, showed more hsc70 than the other lanes. Accumulation of hsc70, constitutive stress protein probably induced by the miscellaneous stresses, was not reduced by the ADM treatment and slightly enhanced by the hyperthermia at 42 or $44^{\circ} \mathrm{C}$ but slightly reduced by the combined treatments with ADM and hyperthermia at $42^{\circ} \mathrm{C}$.

accumulated after the $42^{\circ} \mathrm{C}$ hyperthermia alone during the interval incubation for 6-24 h but was not appreciably accumulated after the combined treatment with ADM and $42^{\circ} \mathrm{C}$ hyperthermia; and h) hsp 72 was accumulated $6-24 \mathrm{~h}$ after the combined treatment with $\mathrm{ADM}$ and $44^{\circ} \mathrm{C}$ hyperthermia, the amount of which was markedly slighter than that after $44^{\circ} \mathrm{C}$ hyperthermia alone. Western blot finding on hsc70 and hsp72 was no more than qualitative finding, but the lower accumulation of hsc 70 was observed after the simultaneous treatments with $\mathrm{ADM}$ and $42^{\circ} \mathrm{C}$ hyperthermia rather than that after $42^{\circ} \mathrm{C}$ hyperthermia alone and no significant difference was observed between groups of the combined treatments and the control. Hsp72 was markedly accumulated $6-24 \mathrm{~h}$ after $42^{\circ} \mathrm{C}$ or $44^{\circ} \mathrm{C}$ hyperthermia alone while it was not appreciably observed after ADM treatment alone, but observed after the combined treatment with ADM and $44^{\circ} \mathrm{C}$ hyperthermia.

\section{Discussion}

Survivals in colony forming unit after a variety of treatments. Several results were obtained from the quantitative assay in 

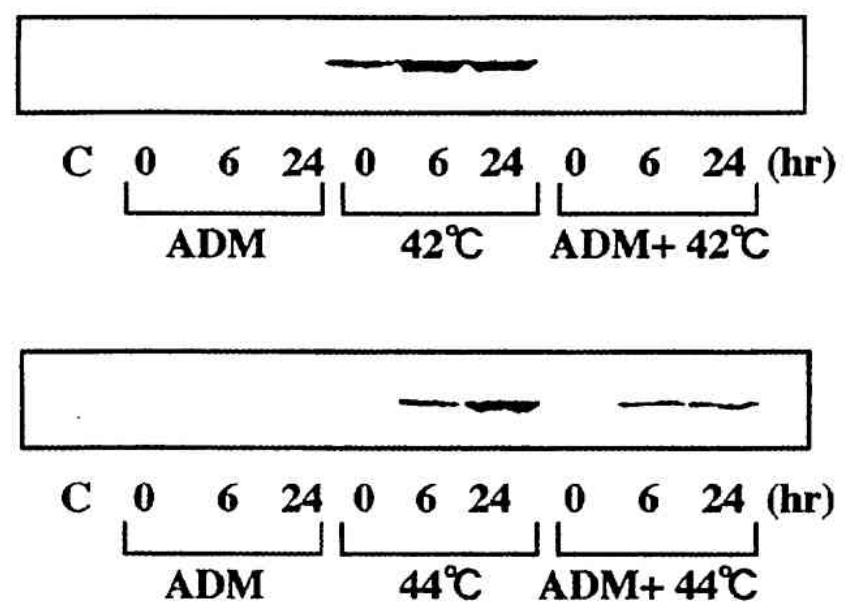

Figure 5. Hsp72 accumulation of V79 cells treated with $\mathrm{ADM}, 42^{\circ} \mathrm{C}$ (upper panel) or $44^{\circ} \mathrm{C}$ (lower panel) hyperthermia, or combined with $\mathrm{ADM}$ and hyperthermia, after the graded periods of incubation intervals. Time course of intracellular accumulation of hsp 72 in V79 cells after the treatments with ADM, hyperthermia or the combination were examined by Western blotting as shown. Numerals on horizontal line of the panels represent $37^{\circ} \mathrm{C}$ incubation intervals in hour between the treatments of ADM, hyperthermia or the combination and the blotting, respectively, and the ' $\mathrm{C}$ ' on the left of the panel represents the lane for hsp72 of the non-treated control V79 cells. Each treatment period was designed $3 \mathrm{~h}$ for $\mathrm{ADM}$ alone, $5 \mathrm{~h}$ for $42^{\circ} \mathrm{C}$ alone and $30 \mathrm{~min}$ for the combined treatments (surviving late in C.F.U. of $10 \%$, respectively), while in the lower panel $20 \mathrm{~min}$ for $44^{\circ} \mathrm{C}$ alone and $10 \mathrm{~min}$ for the combined treatments. All the treatment periods were designed to give isotoxic effect of the cell killing. Hsp72 was accumulated $6-24 \mathrm{~h}$ after $42^{\circ} \mathrm{C}$ or $24 \mathrm{~h}$ after $44^{\circ} \mathrm{C}$ hyperthermia alone that was not appreciably accumulated after ADM treatment alone, but accumulated slightly after the combined treatments with $44^{\circ} \mathrm{C}$ hyperthermia and ADM. In the lanes of control and those after treatment with ADM alone no appreciable accumulation of hsp72 was observed. Hsp 72 was accumulated $24 \mathrm{~h}$ after 42 or $44^{\circ} \mathrm{C}$ hyperthermia but was not accumulated after $A D M$ at $37^{\circ} \mathrm{C}$, while it was slightly recognized 0,6 and $24 \mathrm{~h}$ after combined treatments with $\mathrm{ADM}$ and $44^{\circ} \mathrm{C}$ for $10 \mathrm{~min}$ but was not recognized appreciably 0,6 and $24 \mathrm{~h}$ after combined treatments with $\mathrm{ADM}$ and $42^{\circ} \mathrm{C}$ for $30 \mathrm{~min}$. These blottings indicate $\mathrm{ADM}$ treatment did not appreciably induce hsp72 in the present assay system, and it took six or more hours of intervals after hyperthermia to induce hsp72 but ADM combined with hyperthermia efficiently inhibit accumulation of hsp72.

colony formation by the surviving cells from treatments with hyperthermia at 42 or $44^{\circ} \mathrm{C}$, ADM and the simultaneous treatments. Interaction in enhanced cell killing by simultaneous treatments with hyperthermia and ADM was yielded as shown in Figs. 1 and 3 and Table I. Initial combined short-treatment with hyperthermia and ADM resulted in markedly enhanced cell killing and Western blot analysis after the combined treatment with hyperthermia and ADM resulted in markedly reduced accumulation of hsp 72 rather than that after hyperthermia alone, suggesting inhibition of hsp72 accumulation by ADM, i.e. lower than the theoretically estimated $8.8 \%$. The reduced surviving fraction was much less than the theoretically estimated, suggesting the interactive effect between the treatments of ADM and $42^{\circ} \mathrm{C}$ hyperthermia. It is elucidated that the simultaneous treatments with $\mathrm{ADM}$ and hyperthermia for the initial short period such as $1 \mathrm{~h}$ at $42^{\circ} \mathrm{C}$ or $10 \mathrm{~min}$ at $44^{\circ} \mathrm{C}$ hyperthermia was reasonably indicative to expect marked interactive cell killing.
Enhancement effect of $42^{\circ} \mathrm{C}$ preheating on the lethal chemosensitivity of the thermotolerant V79 cells to ADM, and effect of ADM on survival reduction of thermotolerant V79 cells from step-up $\left(42-44^{\circ} \mathrm{C}\right)$ hyperthermia. Thermotolerance was induced markedly in the V79 cells by the $42^{\circ} \mathrm{C}$ preheating for $2 \mathrm{~h}$, that was examined by the following $44^{\circ} \mathrm{C}$ hyperthermia for the graded periods. Chemosensitivity to $\mathrm{ADM}$ at $37^{\circ} \mathrm{C}$ after the $42^{\circ} \mathrm{C}$ preheating resulted in moderate chemo-enhancement induced by the preheating. Chemosensitivity to $\mathrm{ADM}$ at $44^{\circ} \mathrm{C}$ after the $42^{\circ} \mathrm{C}$ preheating resulted in the same slope of the survival curve to that of ADM at $37^{\circ} \mathrm{C}$. Since the initial $10 \mathrm{~min}$ of the treatments together with $\mathrm{ADM}$ and the $44^{\circ} \mathrm{C}$ hyperthermia after the $42^{\circ} \mathrm{C}$ preheating for $2 \mathrm{~h}$ resulted in markedly interactive cell killing, this survival curve $\left(42^{\circ} \mathrm{C}\right.$ for $2 \mathrm{~h}$ - ADM at $44^{\circ} \mathrm{C}$ ) was drawn parallel to and far below another curve $\left(42^{\circ} \mathrm{C}\right.$ for $2 \mathrm{~h}-\mathrm{ADM}$ at $\left.37^{\circ} \mathrm{C}\right)$ suggesting no appreciable chemical enhancement to ADM by hyperthermia at $44^{\circ} \mathrm{C}$ except for the initial $10 \mathrm{~min}$ of ADM treatment at $44^{\circ} \mathrm{C}$ after the preheating. Although ADM treatment at $37^{\circ} \mathrm{C}$ induced no appreciable hsp72 accumulation, but induced marked accumulation of hsp 72 after 42 or $44^{\circ} \mathrm{C}$ hyperthermia, the combined treatments of ADM and hyperthermia yielded no, or very slight, accumulation of hsp72 indicating that ADM did not only induce accumulation of hsp72 but inhibit hsp72 accumulation owing to the hyperthermia. Quantitative time course assay in colony formation of surviving cells from the variety of treatments with ADM and hyperthermia was hardly interpreted by the qualitative Western blot analysis of the intracellular accumulation of hsc or hsp. P53 status of the V79 cells has been reported mutant type (20). The related problems have been reviewed by the authors (21).

\section{Acknowledgments}

The present work was supported in part by Grants-in-Aids of the Ministry of Education, Science and Culture, Japan, for Scientific Research (A)-1, No. 09307015, (Influence of cancer related genes on radiation effect) 1997-2000 (Head investigator E. Kano, Fukui Med. Univ., Fukui, Japan) and for Cooperative Research (A), No. 04304029, (Co-operative studies on thermosensitivity modifying factors from cells to individuals) 1992-1994 (Head investigator M. Kosaka, Inst. Trop. Med., Nagasaki Univ., Nagasaki, Japan).

\section{References}

1. Arcamone F, Franceschi G, Tenco S and Selva A: Adriamycin (14-hydroxydaunorubicin), a novel antitumor antibiotic. Tetrahedron Lett 13: 1007-1010, 1969.

2. Carter SK: Adriamycin - a review. J Natl Cancer Inst 55: 1265-1274, 1975.

3. Byfield JE, Lee YC and Tu L: Molecular interactions between adriamycin and $\mathrm{X}$-ray damage in mammalian tumor cells. Int $\mathrm{J}$ Cancer 19: 186-193, 1977.

4. Zunino F, Gambetta R, Di Marco A and Zaccara A: Interaction of daunomycin and its derivatives with DNA. Biochim Biophys Acta 277: 489-498, 1972

5. Di Marco A, Zunino F, Silvestrini R, Gambarucci C and Gambetta RA: Interaction of some daunomycin derivatives with deoxyribonucleic acid and their biological activity. Biochem Pharmacol 20: 1323-1328, 1971.

6. Tritton TR, Yee G and Wingard LB Jr: Immobilized adriamycin: a tool for separating cell surface from intracellular mechanisms. Fed Proc 42: 284-287, 1983. 
7. Hahn GM, Braun J and Har-Kedar I: Thermochemotherapy: synergism between hyperthermia (42-43 degrees) and adriamycin (or bleomycin) in mammalian cell inactivation. Proc Natl Acad Sci USA 72: 937-940, 1975.

8. Henle KJ and Dethlefsen LA: Heat fractionation and thermotolerance: a review. Cancer Res 38: 1843-1851, 1978.

9. Jung $\mathrm{H}$ and Kolling $\mathrm{H}$ : Induction of thermotolerance and sensitization in $\mathrm{CHO}$ cells by combined hyperthermic treatments at 40 and 43 degrees C. Eur J Cancer 16: 1523-1528, 1980.

10. Brown IR. Lowe DG and Morgan LA: Expression of heat shock genes in fetal and maternal rabbit brain. Neurochem Res 10: 1277-1284, 1985.

11. Hayashi S, Kano E, Matsumoto H, Hatashita M, Ohtsubo T, Nishida T, Shioura H and Kitai R: Thermosensitivity, incidence of apoptosis and accumulations of hsp 72 and $p 53$ proteins of murine L cells in wild-type status of p53 gene. J Exp Clin Cancer Res 18: 181-189, 1999.

12. Matsumoto $H$, Hayashi S, Shioura $H$, Ohtsubo T, Ohnishi $T$ and Kano E: Suppression of heat-induced hsp 72 accumulation by cisplatin in human glioblastoma cells. Cancer Lett 110: 253-257, 1996.

13. Suzuki $\mathrm{K}$ and Watanabe M: Augmented expression of IISP72 protein in normal human fibroblasts irradiated with ultraviolet light. Biochem Biophys Res Commun 186: 1257-1264, 1992

14. Nogami M, Huang JT, James SJ, Lubinski JM. Nakamura LT and Makinodan T: Mice chronically exposed to low dose ionizing radiation possess splenocytes with elevated levels of HSP70 mRNA, HSC70 and HSP72 and with an increased capacity to proliferate. Int J Radiat Biol 63: 775-783, 1993.
15. Muramatsu T, Ohno H, Shirai T, Takahashi A and Ohnishi T: DNA-damaging agents induce the $72-\mathrm{kD}$ heat shock protein in SV40 transformed normal human fibroblasts. J Dermatol 23: 589-593, 1996.

16. Goto S, Korematsu K, Oyama T, Yamada K, Hamada J, Inoue N, Nagahiro $S$ and Ushio $Y$ : Neuronal induction of $72-\mathrm{kDa}$ heat shock protein following methamphelamine-induced hyperthermia in the mouse hippocampus. Brain Res 626: 351-356, 1993.

17. Elkind MM and Kano E: Actinomycin D and radiation fractionation studies in asynchonous and synchronized Chinese hamster cells. Radiat Res 44: 484-497, 1970.

18. Kano E, Furukawa-Furuya M, Nitta K, Kajimoto-Kinoshita T, Porntipa P, Sugimoto K, Ohtsubo T, Tsuji K, Tsubouchi S and Kondo T: Sensitivities of bleomycin-resistant variant cells enhanced by $40^{\circ} \mathrm{C}$ hyperthermia in vitro. Int $\mathrm{J}$ Hyperthermia 4 : $547-553,1988$.

19. Ohnishi K, Matsumoto $H$, Takahashi A, Wang $X$ and Ohnishi T: Heat shock transcription factor, HSF, is activated by ultraviolet irradiation. Photochem Photobiol 64: 949-952, 1996.

20. Chaung W, Mi LJ and Boorstein RJ: The p53 status of Chinese hamster V79 cells frequently used for studies on DNA damage and DNA repair. Nucleic Acids Res 25: 992-994, 1997.

21. Hayashi S, Kano E, Hatashita M, Ohtsubo T, Katayama K and Matsumoto $\mathrm{H}$ : Fundamental aspects of hyperthermia on cellular and molecular levels. In: Thermotherapy for Neoplasia, Inflammation, and Pain. Kosaka M (ed). Springer-Verlag, pp335-345, 2000. 